\title{
Elderly Blood Donor: the Influence of this Profile in the Hemotherapy Service

João Evangelista Costaa ${ }^{1}$, Francisco Arnoldo Nunes de Miranda', Glauber Weder dos Santos Silva ${ }^{1}$, Michell Platiny Cândido Duarte ${ }^{2}$, Deyla Moura Ramos Isoldi', Ana Michelle Farias de Cabral ${ }^{1}$, Francisca Patrícia Barreto de Carvalho ${ }^{1}$, Rayanne Suelly da Costa Silva ${ }^{1}$, Nayanne Ricelli da Costa Silva', Clélia Albino Simpson ${ }^{1}$

\section{Abstract}

Introduction: A better quality of life and the perspective of a long, productive life are factors that can contribute to maintaining the stocks of blood products.

Objective: The aim of this study is to evaluate the blood donation of the elderly at a private haemotherapy service.

Method: This is a cross-sectional, descriptive investigation conducted at a private haemotherapy service in Natal/RN, Brazil, during July and September 2015 with a sample of 86 elderly individuals. The data were analyzed descriptively.

Results: All the elderly individuals donated blood to meet the needs of one patient. Most of the donors were retirees $(16.2 \%)$, with a high level of schooling $(40.7 \%)$, married $(83.7 \%)$ and residing near the site of the donation $(98.8 \%)$. New blood donations were difficult to obtain, which was attributed to communication via telemarketing (57\%) and personal comorbidities (20.9\%).

Conclusion: The low number of elderly donors can be attributed to misinformation as to the current maximum age limit for donations, comorbidities and the communication/marketing strategy used to attract participants.
1 Federal University of Rio Grande do Norte, Natal, RN, Brazil.

2 University Center of Rio Grande do Norte, Natal, RN, Brazil.

Contact information:

\section{João Evangelista Costa}

Address: Street Trairí, 647, Apartament 204B. Condominium Trairí, Petrópolis, CEP: 59020-150. Natal, RN, Brazil.

”hevan33@oi.com.br 


\section{Introduction}

Advancements in several fields of health, economy, work, science, technology and innovation, among others, have helped increase the lifespan of the world population and considerably contributed to improving the quality of life and life expectancy of people. [1] In Brazil, the reality of the population aging process does not differ from that of the rest of the world.

According to forecasts of the Brazilian Institute of Geography and Statistics (IBGE), the population aged 60 or over climbed from 14.2 million in 2000 to 19.6 million in 2010 and is expected to reach 41.5 million in 2030 and 73.5 million in 2060. In the next ten years, the average growth of the elderly population is estimated at more than 1 million per year. This forecast observes geographical parameters based on the 2010 Demographic Census and more recent information from birth and death records. [1, 2]

Human aging is defined as a progressive, gradual and universal process that involves genetic, biological, social, environmental, psychological and cultural changes. Under a unique perspective, the variability and vulnerability of aging encompass several factors, including the opportunities experienced in life. [3]

Health falls into one of the areas that requires the efforts of society as a whole and specifically targets and converges toward the object of this study: blood donation from people aged 60 or more.

Currently, Ordinance 2712, of 13 November 2013, passed by the Brazilian Ministry of Health (MS/BR), establishes a new age group for blood donation and alters it to a minimum age of 16 years and a maximum of 69 years, 11 months and 29 days. Blood donor candidates between the ages of 16 and 17 years are required to present formal and written consent from a legal guardian for each donation. [4]

The technical standards allow the elderly to donate blood, which shows some progress in the fields of gerontology and haemotherapy. Life expectancy and population aging in relation to blood donation and blood products must be acknowledged and observed when formulating public policies in all social areas in order to effectively increase the number of elderly donors. [5]

Data published by the World Health Organization (WHO) and the MS/BR show that the number of altruistic and regular donors is insufficient to meet the current Brazilian needs. This problem is aggravated with the increasing population, urban violence, diseases like cancer, land accidents and other human needs that, linked to haemotherapy, should be resolved for living and/or surviving. [6]

Another factor that contributes to reducing the amount of blood donors is the high rate of unfit individuals detected during clinical screening (25.23\%). Among the ten most frequent motives for the unsuitability of donors is the high-risk sexual exposure of individuals between 16 and 29 years of age, representing $54.18 \%$ of the surveyed motives of unsuitability, which makes these donors more vulnerable to sexually transmitted diseases. [7, 8]

Knowing the profile of blood donation candidates is therefore essential to ensure transfusion safety, which starts during clinical screening. The profiles are obtained through standardised and structured interviews, followed by serological screening and follow-up of donors based on their loyalty. This management complies with the recommendations of the $\mathrm{WHO}$ and MS/BR to reduce risks related to the transfusion of blood products. [8]

There are three types of donors according to the reason for donating: the replacement donor, who donates for a specific patient; the spontaneous/ homologous donor, who donates to maintain the blood stock; and the autologous donor, when the actual donor will use the collected blood. All three types of donors are considered important for haemotherapy. Evidently, the homologous donor, who donates to help maintain blood stocks, is the best suited and targeted for regular donations. [9] 
Data of the MS demonstrate that, of the Brazilian regions, the northeast has the lowest percentage of homologous donors (43.21\%), while the central west region boasts the highest percentage (79.12\%). [9]

The problem of insufficient donors is not limited to Brazil. Countries like Spain and Portugal face a series of obstacles to maintain their blood stocks and retain a sufficient number of donors, and, as in the case of Brazil, they use replacement donations to minimise this problem. $[10,11]$

In addition to bringing benefits to the patient, donating blood can also benefit the donors. Blood donation reduces the amount of iron (ferritin) in the organism that, when in excess, becomes a risk factor for human health and can cause diseases mainly in the liver (cirrhosis and cancer), heart (myocardial infarction), blood vessels (atherosclerosis) and joints (joint pain), and in glands such as the thyroids (hypothyroidism), pancreas (diabetes) and testicles (hypogonadism). [12, 13]

Donating blood also reduces blood viscosity, which subsequently improves blood flow and possibly limits any damage to the lining of the blood vessels, thus causing less arterial obstructions. [12, 13]

The importance of knowing these benefits surpasses the boundaries of health professionals, especially nurses, and extends to the population by engendering awareness in relation to blood donation and its advantages for the health of patients and donors alike.

Nurses who are qualified and trained in haemodynamics are part of a multi-professional team in the haemotherapy process and play a fundamental role in ensuring the quality of blood, blood products and blood-derived products. Nurses participate in the planning, coordination, supervision, execution and assessment of haemotherapy procedures at the health units and are vital for transfusion safety. [14]

This study is justified by the need to know and expose national standards and publish transfusion guarantees, while targeting elderly donors as a solution to increase blood stocks at haemotherapy services in view of the low number of blood donors in Brazil.

The discussion above poses the question: do elderly donors have a significant bearing on blood stocks at haemotherapy services? This situation leads to the adjacent questions: how many elderly people have donated blood according to the ordinance of the MS? What is the effect of elderly people on the stocks of blood products? How many elderly people attended the call for new blood donations?

Based on these premises, the aim of this study is to evaluate the blood donations of elderly donors at a private haemotherapy service.

\section{Method}

This is a cross-sectional, descriptive study based on data from a private haemotherapy service in the municipality of Natal (RN), Brazil.

The inclusion criteria were blood donors aged 60 to 69 years, 11 months and 29 days, who donated blood from November 11, 2012 to November 12, 2014, who accepted to participate in the survey and responded to telemarketing, who consistently provided telephone number registrations in the online records, and donors who did not have comorbidities after previous blood donations such as cancer, Cerebral Vascular Accident (CVA), insulin-dependent diabetes and/or other causes that rendered them permanently unsuitable for blood donations, according to the existing ordinance. [4]

Exclusion criteria were blood donors under the age of 60 , refusal to participate or lack of response to telemarketing, inconsistent telephone number registration in the online records, and donors who presented the above-mentioned comorbidities and/ or other causes that permanently rendered them unsuitable for blood donations, according to the existing ordinance. [4] 
Research was divided into three stages. The first stage consisted of collecting data from the online health records provided by the specialised software Hemote Plus $®$ to obtain the sociodemographic characteristics of the elderly donors.

Data collection was divided into two periods according to the different age groups established by the ministerial guidelines.

The first period was between November 11, 2012 and November 11, 2013, during which the maximum age for donation was 67 years, 11 months and 29 days. [15]

In the second period, data were collected between November 12, 2013 and November 12, 2014, one year after the enactment of the ordinance in force that altered the maximum age to 69 years, 11 months and 29 days. [4]

The collection occurred in July 2015, using the variables gender, age, type of donor, reason for donating, profession, marital status, level of education and place of residence.

During the second stage, the donors were called for a new donation using a telemarketing tool every Tuesday and Thursday of July, 2015, from 8 to 9 a.m.

The third stage was initiated two months after the second stage, and consisted of checking whether the donors had accepted or rejected a new donation in the donor registrations.

Data were analysed by means of descriptive systematisation of the information obtained from the three research and collection periods.

The research was approved by the research ethics committee of the Universidade Federal do Rio Grande do Norte (CEP/UFRN), decision 1.132.696 of July 01, 2015, and certificate of presentation for ethical appreciation (CAAE) 46209015.0.0000.5537.

\section{Results}

The data collected during the first stage of research, related to the sociodemographic profile of the el-

derly blood donors, created a sample of 86 individuals who met the criteria of inclusion and donated blood from November 2012 to November 2014, as shown the table below: Table 1

Table 1. Sociodemographic characteristics of elderly blood donors. Natal, 2015.

\begin{tabular}{|c|c|c|}
\hline Sociodemographic characteristics & $\mathbf{N}$ & $\%$ \\
\hline \multicolumn{3}{|l|}{ Gender } \\
\hline Male & 62 & $72.1 \%$ \\
\hline Female & 24 & $27.9 \%$ \\
\hline \multicolumn{3}{|l|}{ Age group (years, months and days) } \\
\hline 60 to 67 years, 11 months and 29 days & 78 & $90.69 \%$ \\
\hline 68 to 69 years, 11 months and 29 days & 8 & $9.31 \%$ \\
\hline \multicolumn{3}{|l|}{ Education } \\
\hline Primary school & 16 & $18.6 \%$ \\
\hline Secondary school & 35 & $40.7 \%$ \\
\hline Higher education & 35 & $40.7 \%$ \\
\hline \multicolumn{3}{|l|}{ Marital status } \\
\hline Married & 72 & $83.7 \%$ \\
\hline Single & 8 & $9.3 \%$ \\
\hline Separated & 4 & $4.7 \%$ \\
\hline Widowed & 2 & $2.3 \%$ \\
\hline \multicolumn{3}{|l|}{ Profession/Occupation } \\
\hline Retired & 14 & $16.2 \%$ \\
\hline Civil servant & 9 & $10.5 \%$ \\
\hline Merchant & 7 & $8.1 \%$ \\
\hline Military & 8 & $9.3 \%$ \\
\hline Homemaker & 6 & $7 \%$ \\
\hline Physician & 6 & $7 \%$ \\
\hline Self-Employed & 6 & $7 \%$ \\
\hline Driver & 9 & $10.5 \%$ \\
\hline Engineer & 3 & $3.5 \%$ \\
\hline Other & 18 & $20.9 \%$ \\
\hline \multicolumn{3}{|l|}{ Place of residence } \\
\hline Natal/RN & 70 & $81.4 \%$ \\
\hline Greater Natal/RN & 15 & $17.4 \%$ \\
\hline Another federal state & 1 & $1.2 \%$ \\
\hline \multicolumn{3}{|l|}{ Reason for first donation } \\
\hline Spontaneous/Homologous & 28 & $32.55 \%$ \\
\hline Replacement & 58 & $67.45 \%$ \\
\hline
\end{tabular}


During the call, in addition to explaining the reason for the contact, the donors were also notified of the new maximum age requirements for blood donation established by the ordinance of the MS. [4]

The first 86 elderly contacts were invited to donate blood. Of these 86 contacts, 20 appeared to

Table 2. Reasons that prevented a new blood donation by elderly blood donors. Natal/RN, 2015.

\begin{tabular}{|l|c|c|}
\hline $\begin{array}{l}\text { Reasons for non-performance of new } \\
\text { blood donations }\end{array}$ & N & $\%$ \\
\hline Communication - difficulties in contacting donor \\
\hline No telephone number & 9 & $10.5 \%$ \\
\hline Telephone disconnected/outside area code & 10 & $11.6 \%$ \\
\hline Not answering the telephone & 12 & $13.9 \%$ \\
\hline Disease and treatment & & \\
\hline Underwent surgery during the call period & 5 & $5.8 \%$ \\
\hline Flu during call period & 6 & $6.9 \%$ \\
\hline Sick without defined diagnosis & 2 & $2.3 \%$ \\
\hline Diabetic using insulin & 1 & $1.2 \%$ \\
\hline In cancer treatment & 1 & $1.2 \%$ \\
\hline Hypertensive using beta-blockers & 1 & $1.2 \%$ \\
\hline Sick without defined diagnosis & 2 & $2.3 \%$ \\
\hline Call to donate via telemarketing & & \\
\hline Did not attend and did not justify donation & 18 & $21 \%$ \\
\hline Does not donate at private service & 1 & $1.2 \%$ \\
\hline *Appeared to donate & 20 & $23.2 \%$ \\
\hline Total & 86 & $100 \%$ \\
\hline
\end{tabular}

donate and, of these 20, only eight were over 67 years old.

After the call in the second stage, the reasons that prevented new blood donations were listed and are presented in the following Table 2 .

Table 3 shows the sociodemographic data of eight (8) donors aged between 67 and 69, who donated after being called by telemarketers, collected during the third stage.

Lack of communication represented $36 \%$ of the reasons for not donating, while $20.9 \%$ declared disease/surgical treatment and $22.2 \%$ did not answer the call to donate.

The elderly donors who accepted the invitation and donated blood totalled $9.3 \%$ of the initial group of 86 participants aged between 67 and 69, as established by the ordinance of the MS. [4]

Table 1 shows the number of elderly people who donated blood according to the recommendations set forth in the ministerial ordinances.

Sequentially, tables $\mathbf{2}$ and $\mathbf{3}$ show the effects that donations from elderly people have on the maintenance of blood stocks and how many elderly individuals accepted the call for a new blood donation.

\section{Discussion}

The increasing life expectancy in Brazil and around the world has been proved in a range of studies on this subject. The reduction in mortality rates is the

Table 3. Sociodemographic data of the donors who attended the call for blood donation via telemarketing. Natal/RN, Brazil.

\begin{tabular}{|c|c|c|c|c|c|c|}
\hline Number & Age & Gender & Profession & Marital Status & Education & Place of Residence \\
\hline 1 & 67 & M & Self-Employed & Married & Higher Education & Natal/RN \\
\hline 2 & 68 & M & Military & Married & Higher Education & Natal/RN \\
\hline 3 & 67 & M & Farmer & Married & Primary School & Macaíba/RN \\
\hline 4 & 68 & M & Farmer & Married & Secondary School & João Câmara/RN \\
\hline 5 & 68 & M & Military & Married & Secondary School & Natal/RN \\
\hline 6 & 68 & M & Retired & Married & Primary School & Natal/RN \\
\hline 8 & 67 & M & Physician & Married & Higher Education & Natal/RN \\
\hline 8 & 68 & M & Retired & Widowed & Primary School & Natal/RN \\
\hline
\end{tabular}


result of the fight against diseases, improved nutrition, increased personal and environmental hygiene, better technology for testing, increasingly enhanced treatments and advanced scientific studies in the field of gerontology.

All these factors collaborate and work together to improve quality of life and the perspective of a healthier and longer life. People are aging with more physical and mental health and the elderly can now contribute more in various social areas. [16]

On a global scale, thousands of people are increasingly and constantly in need of blood for a series of inevitable procedures, such as transplants and emergency care. The WHO recommends that $4 \%$ of the population donate blood regularly to maintain the stocks at haemotherapy services. However, data of the MS show that the population has grown and that the number of donors, which totals around $2 \%$, does not accompany this growth and therefore creates a discrepancy between the number of donations and the need for blood transfusions. [10]

Health professionals who work to attract blood donors should not merely consider chronological age when excluding a potential blood donor. Other factors that affect functional age like gender, social class, health, education, level of adaptive capacity and comorbidities make elderly people of the same age group age in different ways. [1] Older individuals can present the necessary requirements to become a blood donor, while younger individuals may not have these requirements and be unfit for donation. [4]

This study found a significant number of elderly blood donors, considering that the minimum and maximum ages for blood donors were only defined in Resolution 343, of December 13, 2002. [17] The number of donors in this study was considered significant since, in addition to the absence of a donation cultural in Brazil, there is latent prejudice in relation to the elderly and even of the elderly in relation to themselves regarding their capacity to perform activities that effectively and positively contribute in all social areas, including blood donation.

Evidence of the findings of this study is provided in the answers of the elderly when they were called for a new donation and claimed that they had passed the right age and/or were too old to donate blood. These findings reveal the urgency of empowering an active aging process, the significance and relevance of this process to the elderly donor and the importance of encouraging the population to donate blood for the stocks of haemotherapy services in order to fully exercise their citizenship.

The results show the lack of information on the maximum age for donating and ignorance of some comorbidities and medicine that do not prevent donations. From another perspective, aging can increase the occurrence of comorbidities, such as cancer, insulin-dependent diabetes, a history of stoke (CVA), among others, which are factors that prevent blood donations.

Despite the rapid development of mobile telephony and the allegedly facilitated communication, contact with the elderly donors was hampered by the absence of phone numbers in the online health records. When the numbers were provided, many participants did not answer the telephone after several attempts.

A recent study addressed the perception of the elderly on the increasingly present information and communication technologies (ICT) and the integration of ICT in the personal, professional and leisure activities of individuals. The vulnerability of ICT was the most cited inhibiting factor by the elderly, who feared being mocked by others or having their privacy invaded through the use of these technologies. [18]

In view of this finding, awareness and publicity actions are needed for the elderly population to help maintain blood stocks, with emphasis on the fact that the maximum age for the first donation is 60 . 
Women are also important contributors in the donation process, considering they are majority in the Brazilian population and, above all, because their health conditions tend to be better than those of the elderly. [4]

Corroborating a study published in 2011 [19], men prevailed among the elderly and married donors who had higher education and who resided near the donation sites. Furthermore, these donors tended to prefer replacement donation, closely followed by spontaneous/homologous donation.

The data showed that when the maximum age for blood donation was 67 years, 11 months and 29 days, 78 individuals donated blood one year before the enactment of the new ordinance. This number corresponds to $1 \%$ of all eligible donors who donated during this period. The new ordinance, among other demands, changed the maximum age to 69 years, 11 months and 29 days. A year after its promulgation, only eight donors over the age of 67 performed a new donation.

It should be noted that only donors over the age of 67 were called to donate, as provided for in the ordinance in force. On the occasion, in addition to being notified of the need of a new blood donation, the donors were informed of the new age requirements established by the ministerial decree, the location of the donation site and the need to attend after having eaten and with a companion.

Marketing was used to call the donors due to its previously corroborated efficiency and because it is considered "a philosophy of action that goes beyond obtaining a donation to meet the need of donors." [11:473]

The donation call is fundamental and can be viewed as a stage of seduction that consists of preparation and conduction. It also determines the good performance of the process and the good progress and success of subsequent activities since it minimises rejection by placing it under the criterion of non-donation.
The potential of the elderly in the maintenance of blood stocks should be noted. Similarly, strategies that transcend telemarketing, such as communication media, email and social networks can maximise new and current donors.

The use of appropriate strategies to stimulate donor loyalty improves blood safety and helps reduce costs during the recruitment of new donors.

In relation to encouraging and calling elderly donors, this tactic potentially saves lives or at least minimises the suffering of patients who need blood products to improve their clinical condition. It should also be noted that each donation produces up to three different blood products that could meet the needs of the same number of patients.

Health professionals, especially nurses, should understand the donor attraction process, observe the current technical regulations for haemotherapy processes and the profile of elderly donors, and continuously perfect the transfusion practice.

\section{Conclusion}

Blood donations from elderly donors have a significant effect on blood stocks and, consequently, on the transfusion process since the younger population tends to have a lifestyle and habits that can make them unsuitable for donation.

The low number of elderly donors can be attributed to misinformation regarding the age limit for donation, comorbidities and the communication or marketing strategy used to call potential donors.

The donor research strategy, albeit current and widely used by companies and services, may have failed to convince the target audience, as portrayed in the results and communication difficulties, which does not make this strategy unfeasible or less relevant.

Health professionals, especially nurses, should therefore target, approach and give credit to elderly donors as collaborators at haemotherapy services since they can potentially form and strengthen a 
culture of blood donation in Brazil, become a social reference in a society that is still unaware of the donation process, and help demystify the fear, prejudice and taboos that surround this process.

\section{References}

1. Carolino JA, Soares ML, Cândido GA. Envelhecimento e cidadania: possibilidades de convivência no mundo contemporâneo. Qualit@s Rev. Eletrônica. 2011; 1(1):1-11.

2. Instituto Brasileiro de Geografia e Estatística (Brasil). Mudança demográfica no Brasil no início do século XXI: subsídios para as projeções da população. Rio de Janeiro: IBGE; 2015.

3. Campos ACV, Ferreira EF, Vargas AMD. Determinantes do envelhecimento ativo segundo a qualidade de vida e gênero. Ciênc. Saúde Coletiva. 2015; 20(7):2221-2237.

4. Ministério da Saúde. Portaria $n^{\circ} 2.712$ de 12 de novembro de 2013. Redefine o regulamento Técnico de Procedimentos Hemoterápicos. [Internet]. Brasília (Brasil); 2013. Available at: http://bvsms.saude.gov.br/bvs/saudelegis/gm/2013/ prt2712 12 11 2013.html

5. Dawalibi NW, Goulart RMM, Prearo LC. Fatores relacionados à qualidade de vida de idosos em programas para a terceira idade. Ciênc. Saúde Coletiva. 2014; 19(8):3505-3512.

6. Malheiros GC, Oliveira AAST, Pinheiro CB, Monteiro KNO, Abreu AMOW. Fatores associados à motivação da doação sanguínea. Rev. Cient. FMC. 2014; 9(1):8-12.

7. Neiva GTV, Erica FSS, Oliveira DLB, Sousa NBT, César PA, Cláudia RMD. Triagem clínica do processo de doação de sangue: análise da recusa dos doadores. Rev. Enferm. UFPE Online. 2015; 9(supl. 1):424-430.

8. Rohr JI, Boff B, Lunkes DS. Perfil dos candidatos inaptos para doação de sangue no serviço de hemoterapia do hospital Santo Ângelo, RS. Rev. Patol. Trop. [online]. 2012; 41(1):27-35.

9. Brasil. Ministério da Saúde. Caderno de informação: Sangue e Hemoderivados [Internet]. Brasília (Brasil); 2014. Available at: http://bvsms.saude.gov.br/bvs/publicacoes/ caderno informacao sangue hemoderivados 7ed.pdf

10. Giacomini L, Lunardi Filho WD. Estratégias para fidelização de doadores de sangue voluntários e habituais. Acta Paul Enferm. 2010; 23(1):65-72.

11. Aldamiz-Echevarria C, Aguirre-Garcia MS. Um modelo comportamental de doadores de sangue e estratégias de marketing para atração e fidelidade. Rev. Latino am. Enferm. 2014; 22(3):467-475

12. Holsworth RE Jr, Cho YI, Weidman JJ, Sloop GD, St Cyr JA. Cardiovascular benefits of phlebotomy: relationship to changes in hemorheological variables. Perfusion, 2014; 29(2):102-116.
13. Goot K, Hazeldine S, Bentley P, Olynyk J, Crawford D. Elevated serum ferritin: What should GPs know? Australian Family Physician. 2012; 41(12):945-949.

14. Conselho Federal de Enfermagem. Resolução n 306/2006. Normatiza a atuação do Enfermeiro em Hemoterapia [Internet] Rio de Janeiro (Brasil); 2006. Available at: http://sig.corenmg. gov.br/sistemas/file/doc/legislacoes/docs/doc legis 93.pdf

15. Ministério da Saúde. Portaria $n^{\circ} 1.353$ de 13 de junho de 2011. Dispõe sobre os procedimentos hemoterápicos [Internet]. Brasília (Brasil); 2011. Available at http://brasilsus.com.br/legislações/ gm/108 431-1353.html.

16. Wendt CJK, Aires M, Paz AA, Fengler FL, Paskulin LMG. Elderly families of South of Brazil in the Health Strategy. Rev. Bras. Enferm. 2015; 68(3):350-357.

17. Brasil. Ministério da Saúde. Resolução $n^{\circ} 343$, de 13 de dezembro de 2002. Determina o regulamento técnico para os procedimentos hemoterápicos. [Internet). Brasília (Brasil); 2002. Available at: http://www.aeap.org.br/doc/resolucao rdc 343 de 13 de dezembro de 2002.pdf

18. Farias JS, Vitor TL, Lins PV, e Pedroza Filho LEA. Inclusão digital na terceira idade: um estudo sobre a propensão de idosos à adoção de tecnologias da informação e comunicação (TICS). Rev. Gestão Tecnol. 2015; 15(3):164-188.

19. Belato D, Weiller TH, Oliveira SG, Brum DJT, Schimith MD. Perfil dos doadores e não doadores de sangue de um município do sul do Brasil. Rev. Enferm. UFSM. 2011; 1(2):164-173.
Publish in International Archives of Medicine

International Archives of Medicine is an open access journal publishing articles encompassing all aspects of medical science and clinical practice. IAM is considered a megajournal with independent sections on all areas of medicine. IAM is a really international journal with authors and board members from all around the world. The journal is widely indexed and classified Q1 in category Medicine. 